\title{
Models and specifics of interaction between universities and stakeholders
}

Konstantin V. Vodenkoa*, Platov South-Russian State Polytechnic University (NPI), Novocherkassk, Russia. https://orcid.org/0000-0002-5283-0466

Yuri G. Volkovb , Southern Federal University, Rostov-on-Don, Russia. https://orcid.org/0000-0001-5696-1570

Vladimir I. Kurbatov c, Russian Academy of Sciences (South-Russian branch), Moscow, Russia https://orcid.org/0000-0002$\underline{5342-3657}$

Svetlana A. Tikhonovskova d, Platov South-Russian State Polytechnic University (NPI), Novocherkassk, Russia https://orcid.org/0000-0002-6085-2403

Marianna L. Krolman e, Rostov State University of Economics, Rostov-on-Don, Russia. https://orcid.org/0000-0002-0913-6196

Galina I. Bolshakova f ,_Rostov State Transport University, Rostov-on-Don, Russia. https://orcid.org/0000-0002-5332-3669

\section{Suggested Citation:}

Konstantin V. Vodenko, Yuri G. Volkov, Svetlana A. Tikhonovskova, Marianna L. Krolman \& Galina I. Bolshakova (2021). Models and Specifics of Interaction between universities and stakeholders. Cypriot Journal of Educational Science. 16(5), 2690-2697. https://doi.org/10.18844/cjes.v16i5.6357

Received from 10 June, 2021 ; revised from August 20, 2021; accepted from October 15, 2021.

(C)2021 Birlesik Dunya Yenilik Arastirma ve Yayincilik Merkezi. All rights reserved.

\begin{abstract}
One of the world's leading social trends in development of higher education of the twenty-first century is progression of relationships between universities and business. The main purpose of this paper is to compare the models of integration between universities and business, considering the triple model of social partnership, the model with the dominant role of the state, and the model of mixed representation, typical for the Central European countries. The methodological framework of this research includes methods of statistical and comparative analysis and synthesis. From the results of this research, European higher education has developed and effectively operates the developed models of interaction between institutions of higher education and business. The obtained results allow us to evaluate the possibilities of applying positive foreign experience in Russian reality.
\end{abstract}

Keywords: university, education, government, business, research, integration of education and business, models of interaction between universities and business.

* AdDRESS FOR CORRESPONDENCE: Konstantin V. Vodenkoa, Platov South-Russian State Polytechnic University (NPI), Novocherkassk, Russia.

Email address: vodenkok@mail.ru 


\section{Introduction}

One of the world's leading social trends in development of higher education of the XXI century is progression of relationships between universities and business (Armstrong \& Earle, 2012). An actual practical and theoretical task in this regard is to develop some models for interaction of the training system with the needs and orders of business community (Bayanova et al., 2019). Traditionally, a set of issues specific to this sector includes monitoring, planning and forecasting of regional labor markets development, determining the need for specialists, quantitative and qualitative study of the volume and structure of training, creation of a common database on the state of training, needs of the labor market, the sought-after modern professions and the prospects of training, strategic partnerships of universities (Tugun et al., 2020), business entities, organizations and enterprises, providing high-quality training and retraining to meet the current and future needs of the regions (Lane \& Johnstone, 2013).

The logic and structure of this research is based on classification of the main models of interaction between universities and stakeholders on the following grounds:

- the role of public administration in the system of social partnership,

- degree of development of social institutions (organizing and implementing social partnership between universities and business community),

- involvement of business community in the process of developing requirements for the quality system of university graduates,

- financing of the interaction between professional training system and business,

- the forms, methods and levels of innovative and technological infrastructure intended for implementation in the system of higher education and business community.

There are some classifications, based on other grounds: for example, on ideological or on the role of trade unions in the process of interaction between universities and business, on orientation of the social partnership system itself, (such as the social democratic, conservative, socialist systems). These parameters require introduction of ideological and political characteristics into the corresponding discourse for conceptual reconstruction of the models, which is beyond professional consideration (National Education Association, 2020).

\subsection{Purpose of study}

The problems of interaction between universities and various stakeholders are widely discussed in the modern scientific literature. In this regard, it is necessary to highlight the works of such domestic and foreign authors as Ashmarina and Kandrashina (2011), Gibson (2004), Amendment (2014), Damyanova (2013), Karpov (2014a; 2014b), Kekkonen and Sigova (2016), Lukichev (2005), Khairullina et al. (2020), Rodin (2011), Gimaliev et al. (2020) and other authors. The purpose of this article is to think on the European models of interaction between universities and business community, conducting comparative analysis and assessment of their suitability in the Russian Federation.

\section{Methodological Framework}

\subsection{Design}

This research was qualitative research with a descriptive research design. This paper is to compare the models of integration between universities and business. The research methodology is also based on the stakeholder theory. The key provisions of this concept in relation to universities can be 
interpreted as follows: the social significance, value, popularity, and attractiveness of the university is not created by itself but is the result of complex interaction and cooperation of stakeholders.

Methodological framework of this study is based on consideration of the parameters related to characterological features of the institute of education as the most important social institution, on the basis of which they distinguish several models of interaction between universities and stakeholders.

\subsection{Participants and Data Collection tool}

The research collected secondary data from previous literature therefore there were no participants. The data was collected through websites and scholarly journals.

\subsection{Analysis}

Methodological framework of this research includes methods of statistical and comparative analysis and synthesis.

\section{Findings}

The first model is a three-way partnership one. The main social partners of this model are the universities themselves, the state (Federal research structures) and business (industrial organizations, business community, trade associations). The most pronounced representative of this model is the system of interaction between the training system (higher professional education) and business of the modern Great Britain.

In the UK, the main model for cooperation between universities and business is creation of various organizations and public institutions, which include educational, research, business and trade associations and firms that transfer innovative technologies to the higher education system and business community. For this purpose, there was created The Higher Education Innovation Fund (HEIF).

This organization allocates funds to the universities in order to open offices to coordinate their activities with business, transfer innovative technologies, provide marketing analysis of research activities, career guidance and educational services to businesses. These services are expressed in creation of special firms providing students and graduates with training in entrepreneurial skills, professional advice related to their profile and choice of their future workplace.

The Federal structures act as cooperative partners in interaction between universities and business community. In particular, they are the initiators and intermediaries in cooperation of universities' research structures and businesses. The objectives of such cooperation are, first, to transfer the innovative technologies from the state scientific sector to the private enterprise one, second, to stimulate the use of innovative technologies in higher education institutions and in business, and third, to create joint (business community and universities) cooperative research centers.

For this reason, there is carried out clustering of socio-economic, administrative, and territorial space. Experience has shown that the problem of interaction between universities and business for mutual benefit is most effectively resolved in those regions where these clusters operate effectively, i.e.: the complexes of business structures, industrial companies, trade associations, Federal and university research centers, universities as professional training centers and specialized firms, providing consulting and career guidance to universities and the business community function (Kekkonen \& Sigova, 2016). 
To coordinate the actions of all the agents of this cluster, in the UK there have been created the Sector Skills Councils. Their task is to reduce the distance between universities and business, improve the efficiency of both universities, businesses and relevant investments that contribute to increase of demand for the graduates by improving the quality of their professional knowledge and skills, the quality of professional education.

These councils, which include representatives of institutions of higher education, Federal and university research structures, business, industrial enterprises, and trade associations are social institutions that shape the development of higher education related to improving the quality of graduate training, resulting from the needs of society and business in qualified personnel, forming development strategies of various sectors of business and economy. They also form a system of social incentives to motivate the employers, closely coordinating their activities with the professional training system (Gibson, 2004).

The model of interaction between universities and business in France, for all its specifics and national features, is also threefold as in the UK (Apkarova, 2008). Let's summarize the main features of this social model of trilateral cooperation.

First, it is a three-way partnership model (the state, the system of higher education and business), while the state is not so much a decision-making body, but a social partner, interested in effective transfer of innovative technologies from the Federal research sector to business and education, in encouraging more efficient use of innovative technologies, both in universities and in business, and in creating joint cooperative research centers for the business community and universities.

Second, social funds and professional communities are responsible for financing this interaction and organizing targeted investments. Third, the coordination of trilateral cooperation is taken over by the Sector Skills Councils (focused on certain sectors, both business and professional training of specialists), reducing the distance between universities and businesses and forming administrative and territorial clusters.

Fourth, the essence of the tripartite model of interaction between the government, higher education and business consists in organization of effective interaction of such spheres as education, science, and business, which is formation of social institutions on the basis of which they form the technological infrastructure for innovations, both in higher education and in business.

The second model is typical for the Nordic countries (Finland, Sweden, Belgium, Norway, and the Netherlands). This model is associated with the active role of the state in interaction of higher education and business. According to the modern researchers, in this scheme of interaction the state regulates social partnership at the national level, at the industry level and at the level of specific industrial enterprises and business organizations. The state's regulation is carried out through creation of parity commissions, which are controlled by the government.

The third type is the social partnership between higher professional education and business in such a way that the government can regularly conduct consultations between the national trade unions, including the trade unions of institutions of higher education and unions of entrepreneurs. At this level, social partners reach agreements on social policy in the field of higher professional education and its participation in business.

This model is also called the mixed representation model and involves joint decisions aimed at mutually beneficial consensus in activities of universities and business unions. The most complete specificity of this model is characterized by the established practice of interaction between higher 
education institutions and business in Germany. At the same time, in contrasts with the second statecentered model, as in Germany the autonomy of higher education institutions significantly limits the influence of state authorities. When it comes to specific organization of educational activities and coordination of educational quality systems with business needs, decisions are usually made within the professional competence.

\section{Discussion}

It should be noted that the analyzed European experience is based on the so-called Bologna process, which was the basis for major changes in reformatting European higher education. The main trend in this process is the focus on developing the necessary competencies, special and professional skills in training, based on introduction of innovations in the educational process that are in demand in society as a whole and in business in particular (Brazhnik \& Lavrentieva, 2010).

The European concept of higher education is focused on effectiveness of universities' activities. In this regard, the leading European experts point to the pragmatic and practical orientation of training. This is reflected in orientation of universities to the needs and demands of the labor market. An important condition for this orientation is the need to improve competitiveness of universities. Accordingly, orientation of their educational programs to the needs of the labor market is one of the most important indicators of effectiveness of higher education.

The strategies of higher education institutions with their focus on professional competencies meeting the needs of the labor market are reflected in the change of education concept itself. It is based on progress and innovations in the educational process methods, models of continuous learning, selfdevelopment skills, modular methodology of educational programs and comprehensive implementation of modern communication and information technologies in the training process. The new concept of higher education is aligned with the following idea: a high-quality product of educational process is a well-trained and constantly improving professional. This leads to a new type of higher education institutions (Canals, Diebolt \& Jaoul, 2003).

Within the framework of this concept the employer is treated as an interested party in improving the quality of educational process. It is expressed not only in increase of business contribution to development of higher education, but also in determining the specific goals and objectives of training by business community. This radically changes the relationships between universities and employers. Both sides, as equal partners, achieve coordinated interaction, being aware of each other's needs and interests, acting in concert and creating specific cooperation institutions on terms of mutual benefit (Dernières nouvelles de la Russie, 2017).

In our opinion, in relation to Russia it is advisable to take into account the European experience of formation and functioning of such a system as the basis for interaction of higher professional education system. At the heart of everything there is the quality system of education. In contrast to the system of European higher professional education, the quality of education of a state university is evaluated only by the state, creating a kind of vicious circle. The established European and world practice has shown that education as a social institution is not limited only to the state's requirements and standards. The quality of education should be evaluated by all the interested participants, namely, other universities (competition, ratings) and consumers of educational services (other social institutions, government agencies, industrial enterprises, business structures, trade associations). 


\section{Conclusion}

The main conclusion of this study is that practice requires quality of training, but this is not the sufficient condition. Those who participate in assessment of students' training quality, i.e., those who are interested in highly qualified specialists to work in their structures should not only evaluate their quality, but also participate in creating conditions for their training, formulating not only the quality standards, but material resources for their implementation (grants, investments, personal scholarships, financing of joint centers of expertise, project implementation, etc.). But direct participation of business organizations for training their own personnel is also not sufficient.

Currently, they implement the pan-European concept, which is related to the agreed development plan as a complex for coordinating development of higher education in the EU. It includes several main blocks (European Commission, 2011).

The first one is related to the coordination of interstate relations in the field of higher education. The second one is focused on the measures to bring scientific research closer to the needs of society, economy, industry, and business. The third one is related to development of incentives aimed at increased funding for higher education by the state and business.

The fourth one is focused on stimulating development of technological innovations in educational process. The fifth one describes the measures aimed at increasing the role of universities as drivers of social and business development (Karpov, 2014a; Karpov, 2014b).

The market needs for personnel are the needs of today, or at best, of the near future. Practice shows that research work that is potentially in demand in the future as implementation of socially significant and national task should be based on development of appropriate social institutions and public scientific funds to support the basic scientific research and promising research areas (Brazhnik \& Lavrentieva, 2010).

Some foreign models of relationships between universities and the business community are formed in so-called "network universities" (which have become widespread in recent years), creative and innovative entrepreneurial universities. Understanding of these models is essential for further research and scientific publications.

\section{Acknowledgments}

The research was performed within the grant of the President of the Russian Federation for state support for the leading scientific schools of the Russian Federation (NSh-2582.2020.6) «Public policy in the field of higher education and development of innovative potential of youth: economic and noneconomic determinants and mechanisms in conditions of regionalization of social space and formation of industry $4.0 \%$.

\section{References}

Amendment, I.Y. (2014). Cooperation between business and universities: the possibilities for both sides. Personnel Management, 2, 28-29. https://cyberleninka.ru/article/n/analiz-uspeshnogo-opyta-vzaimodeystviyavuzov-s-biznes-strukturami

Apkarova, E. (2008). The Bologna Process and the System of Higher Education in France. Higher Education in Russia, 10, 112-115. https://cyberleninka.ru/article/n/15493168 
Konstantin V. Vodenko, Yuri G. Volkov, Svetlana A. Tikhonovskova, Marianna L. Krolman \& Galina I. Bolshakova (2021). Models and Specifics of Interaction between universities and stakeholders. Cypriot Journal of Educational Science. 16(5), $2690-2697$. https://doi.org/10.18844/cjes.v16i5.6357

Armstrong, M., Earle, L. (2012). Sustained Blended Professional Development in the $21^{\text {st }}$ Century. URL: http://etec.ctlt.ubc.ca/510wiki/Sustained Blended Professional Development in the 21st Century.

Ashmarina, S.I., Kandrashina, E.A. (2011). Concepts of Cooperation Between Universities and Enterprises in the Framework of International Projects. Bulletin of Samara state University of Economics, 81, 5-9. https://elibrary.ru/item.asp?id=17091187

Bayanova, A.R., Vodenko, K.V., Sizova, Zh.M., Chistyakov, A.A., Prokopiev, A.I., \& Vasbieva, D.G. (2019). A philosophical view of organizational culture in contemporary universities. European Journal of Science and Theology, 15(3), 121-131. http://www.ejst.tuiasi.ro/Files/76/11 Bayanova\%20et\%20al.pdf

Brazhnik, E.I., Lavrentieva, O.G. (2010). Features of Development of University Education in France and in Russia in the Context of the Common European Educational Space. St.Petersburg: RSPU. https://elibrary.ru/item.asp?id=22788294

Canals, V., Diebolt, C., Jaoul, M. (2003). Convergence et Disparités Régionales du Poids de L'enseignement Supérieur en France: 1964-2000. Revue D'économie Régionale et Urbaine, 4, 32-41. https://www.cairn.info/revue-d-economie-regionale-et-urbaine-2003-4-page-649.htm

Damyanova, L.T. (2013). Experience of European Countries in Creating a New Type of Universities. Creative economy, 7(12), 95-101. https://cyberleninka.ru/article/n/16635745

Dernières nouvelles de la Russie. (2017). L'association des Professeurs de la Langue Russe a Proposé de Créer en Russie une "Linguistique de la Police". URL: http://frahhh!news-4-u.ru/lassociation-des-professeurs-de-lalangue-russe-a-propose-de-creer-en-russie-une-linguistique-dela-police.html

European Commission. (2011). Council Conclusions on the Role of Education and Training in the Implementation of the Europe 2020 Strategy. Official Journal of the European Union, № 4, 71-73. https://elibrary.ru/item.asp?id=25392598

Gibson, M. (2004). Business and Higher Education: Experience of Interaction in Great Britain. University Management: Practice and Analysis, 4(32), 53-66. https://cyberleninka.ru/article/n/14992604

Gimaliev, V.G., Prokopyev, A.I., Vershinin, V.P., Ivanova, M.E., Erkibaeva, G.G., Aytuganova, J.I., \& Alexandrova, N.S. (2020). Public Relations in Organizations in Student View: Accumulator of Management Tools or Formation of Partnership and Friendly Relations. Journal of environmental treatment techniques, 8(4), 1326-1330. https://elibrary.ru/item.asp?id=43945274

Karpov, A.O. (2014a). Modern University as a Driver of Economic Growth: Models and Missions. URL: http://institutiones.com/general/2975-sovremennyi-universitet.html

Karpov, A.O. (2014b). Modern University: Environment, Partnerships, Innovations. Alma Mater. High School Messenger, 8, 8-12. https://elibrary.ru/item.asp?id=21842647

Kekkonen, A.L., Sigova, S.V. (2016). Innovations Development of Models of Cooperation between Higher Education and Business: European and Russian Experience. URL: http://net.knigi-x.ru/24ekonomika/291217-1-udk3784-sedunov-sedunova-modeli-vzaimodeystviya-universiteta-delovogo-soobschestva-evropeyskiy.php

Khairullina, E.R., Shubovich, M.M., Bogdanova, V.I., Slepneva, E.V., Mashkin, N.A., \& Rodyukova, T.N. (2020). Modern student youth civic identity: Political activity or social responsibility? Opcion, 36(Special Edition 27), 1703-1717. https://dialnet.unirioja.es/servlet/articulo?codigo=7667451

Lane, J.E. \& Johnstone, D.B. (2013). Higher Education System 3.0: Adding Value to States and Institutions. Higher Education System 3.0: Harnessing Systemness, Delivering Performance. SUNY Press, 6(12), 3-26. https://eric.ed.gov/?id=ED573016

Lukichev, G. (2005). In Search of Effective Interaction between Higher Education and Employers. Economics of Education, 4, 5-21. https://elibrary.ru/item.asp?id=9171589

National Education Association. (2020). Preparing $21^{\text {st }}$ Century Students for a Global Society: An Educator's Guide to the «Four Cs». URL: http://www.nea.org/assets/docs/A-Guide-to-Four-Cs.pdf

Rodin, I.V. (2011) Higher Education in France and its Study in Modern French Historiography. New and modern history, 6, 125-135. 
Konstantin V. Vodenko, Yuri G. Volkov, Svetlana A. Tikhonovskova, Marianna L. Krolman \& Galina I. Bolshakova (2021). Models and Specifics of Interaction between universities and stakeholders. Cypriot Journal of Educational Science. 16(5), $2690-2697$. https://doi.org/10.18844/cjes.v16i5.6357

Tugun, V., Bayanova, A.R., Erdyneeva, K.G., Mashkin N.A., Sakhipova, Z.M., \& Zasova, L.V. (2020). The Opinions of Technology Supported Education of University Students. International Journal of Emerging Technologies in Learning, 15(23), 4-14. https://www.learntechlib.org/p/218460/ 